\title{
Viral hepatitis in a Canadian First Nations community
}

\author{
GY Minuk $M D^{1}$, M Zhang $M D^{1}$, SGM Wong $M D^{1}$, J Uhanova MD PhD ${ }^{1}, C N$ Bernstein $M D^{2}$, \\ B Martin $\mathrm{MD}^{3}$, MR Dawood PhD ${ }^{4}, \mathrm{~L}$ Vardy ${ }^{5}$, A Giulvi MD
}

\begin{abstract}
GY Minuk, M Zhang, SGM Wong, et al. Viral hepatitis in a Canadian First Nations community. Can J Gastroenterol 2003;17(10):593-596.

Serological markers for hepatitis A (HAV), B (HBV) and C (HCV) were documented in 315 inhabitants (27\%) of a central Manitoba First Nations community. Serologic evidence of HAV infection (antiHAV positive) was almost universal (92\%) by the age of 20 years. HBV infection (antibody to hepatitis B core antigen positive) had occurred in only $2.3 \%$ of the study population and no chronic carriers were identified. Serological evidence of HCV infection (antiHCV positive) was documented in $2.2 \%$ of the population but ongoing viremia (HCV-RNA positive by polymerase chain reaction) was absent. The results of this study highlight the importance of universal HAV vaccination; likely reflect the efficacy of existing prenatal screening and immunoprophylaxis programs for HBV; and raise the possibility that First Nations peoples have an enhanced ability to spontaneously clear HCV.
\end{abstract}

\section{L'hépatite virale dans une communauté canadienne des Premières nations}

Les marqueurs sérologiques d'hépatite $\mathrm{A}$ (VHA), d'hépatite $\mathrm{B}$ (VHB) et d'hépatite $\mathrm{C}$ (VHC) ont été documentés chez 315 habitants (27\%) d'une communauté des Premières nations du centre du Manitoba. L'infection au VHA (positif à l'anticorps anti-VHA) était presque universelle (92\%) à 20 ans. L'infection au VHB (positif à l'antigène capsidique de l'hépatite B) ne se manifestait que chez 2,3\% de la population à l'étude, et aucun porteur chronique n'a été dépisté. Des signes sérologiques d'infection au VHC (positif à l'anticorps anti-VHC) ont été documentés chez 2,2 \% de la population, mais il n'y avait pas de virémie (ARN du VHC positif d'après la réaction en chaîne de la polymérase). Les résultats de cette étude démontrent l'importance d'une vaccination universelle contre le VHA, reflètent probablement l'effet des programmes de dépistage prénatal et d'immunoprophylaxie du VHB et soulèvent la possibilité fascinante (entre autres) que les peuples des Premières nations manifestent une capacité accrue de guérir spontanément du VHC.

Key Words: Canada; Epidemiology; First Nations; Hepatitis; Hepatitis A; Hepatitis B; Hepatitis C; Liver

$\mathrm{T}$ he availability of safe, effective immunoprophylaxis and/or treatment for the most common causes of viral hepatitis in North America underscores the importance of identifying which segments of the population are at greatest risk of such infections (1). Poor socioeconomic conditions, high rates of sexually transmitted diseases and injection drug use have been associated with increased prevalences of hepatitis A (HAV), B (HBV) and $\mathrm{C}(\mathrm{HCV})$ and are common features of the Canadian First Nations population (2-4). Yet, to date, only one study has reported the prevalence of viral hepatitis in this group (5). Moreover, that report was limited to HBV and involved First Nations settlements in far northern Canada (Northwest Territories) which may not reflect findings in the rest of the country, where access to urban centres, sex trade workers and illicit drugs are more readibly available.

The purpose of the present study was to document the prevalence of serological markers for HAV, HBV and HCV infection in a community-based, First Nations population located in central Manitoba.

\section{SUBJECTS AND METHODS}

The study community is located in central Manitoba and has a population of 1036, of whom $90 \%$ are Cree (6). Forty per cent of the population is under the age of 12 years. The majority of inhab- itants follow the traditional lifestyles of hunting, trapping and fishing. Housing is crowded, sanitary facilities are primitive and running water is lacking. The prevalences of sexually transmitted diseases and injection drug use have not been documented but are thought to be high by local health care deliverers. Scheduled flights to Winnipeg, the largest urban centre in the region, are available on a daily basis. Prenatal HBV screening programs were implemented in 1994 and childhood HBV vaccination programs for grade 5 children in October 1999.

Approval for the study was obtained from the Chief and governing council of the community, the regional Tribal Council and the University of Manitoba Research Ethics Board. Local community health workers assisted in community education regarding the aims and objectives of the study, and secured permission to test the blood samples for viral hepatitis.

Sera were obtained from 315 of the estimated 518 individuals $(61 \%)$ residing in the community at the time of the study (summer of 1999). These individuals had been recruited for an earlier Helicobacter pylori/gastric disorder prevalence study by advertisements on community radio and television as well as posters placed in public meeting areas. Sera were stored at $-70^{\circ} \mathrm{C}$ until thawed for testing in 2000. Subjects under 15 years of age were discouraged from participating in the study due to investigators' concerns regarding anxiety associated with needle sticks in this age group.

Sections of ${ }^{1}$ Hepatology and ${ }^{2}$ Gastroenterology, Department of Medicine; ${ }^{3}$ Northern Medical Unit, University of Manitoba, Winnipeg, Manitoba;

${ }^{4}$ Cadham Provincial Laboratory and ${ }^{5}$ Laboratory Centre for Disease Control, Blood Borne Pathogen Division, Health Canada, Ottawa,

Ontario

Correspondence and reprints: Dr Gerald Y Minuk, Section of Hepatology, John Buhler Research Centre, 803F-715 McDermot Avenue,

Winnipeg, Manitoba R3E 3P4. Telephone 204-789-3204, fax 204-789-3971, e-mail gminuk@cc.umanitoba.ca

Received for publication April 24, 2003. Accepted July 15, 2003 


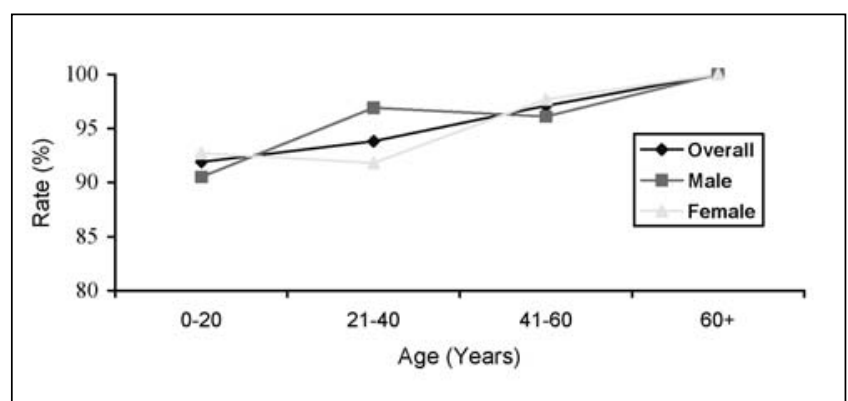

Figure 1) Anti-hepatitis A positive rates (\%) by age and sex in 315 inhabitants of a First Nations community in central Manitoba

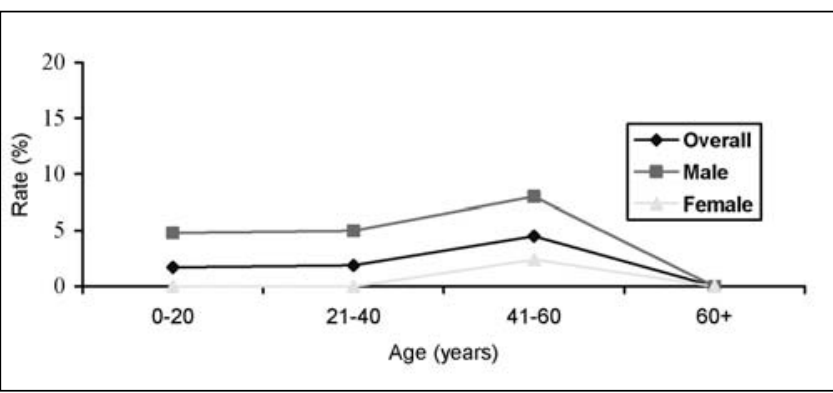

Figure 2) Antibody to hepatitis B core antigen positive rates (\%) by age and sex in 301 inhabitants of a First Nations community in central Manitoba

Nonetheless, $11(3.6 \%)$ of the study population were under the age of 15 years.

Samples were tested by microparticle enzyme immune assay for immunoglobulin (Ig) G antibody to HAV (IgG anti-HAV, Havab, Abbott Laboratories, USA), antibody to hepatitis B core antigen (anti-HBc, Core, Abbott Diagnostics, Germany) and antibody to HCV (anti-HCV, HCV version 3.0, Abbott Diagnostics, Germany). Sera that tested positive for anti-HBc were then tested for hepatitis B surface antigen (HBsAg, Abbott Diagnostics). Those positive for anti-HCV on two separate occasions were further tested for HCV-RNA by reverse transcriptase polymerase chain reaction (RT-PCR, Amplicor version 2, Roche Diagnostics, Canada). The sensitivity of HCV-RNA testing was $50 \mathrm{IU} / \mathrm{mL}$ and specificity $98 \%$. All tests were performed by the Cadham Provincial Laboratory in Winnipeg, Manitoba.

A $\chi^{2}$ test was used to compare proportions and a Student's $t$ test to compare means. All data analyses were performed using the Statistical Package for the Social Sciences software for windows (version 9.0).

\section{RESULTS}

Sera were available from 315 individuals (27\% of the total community population and $61 \%$ of the estimated population residing in the community at the time of the study). Of the 315 , 307 (97.5\%) were First Nations and eight (2.5\%) white. There were 118 males (37.3\%) and 197 (62.7\%) females. The mean ages of males and females were similar $(34.4 \pm 15.1$ versus $34.3 \pm 15.6$ years) and ranged from 1.5 to 82 years.

\section{Hepatitis A}

Sufficient serum was available for anti-HAV testing in all 315 samples. A total of $298(94.6 \%)$ tested positive for IgG antiHAV. Positive rates in males and females were similar $(95.8 \%$

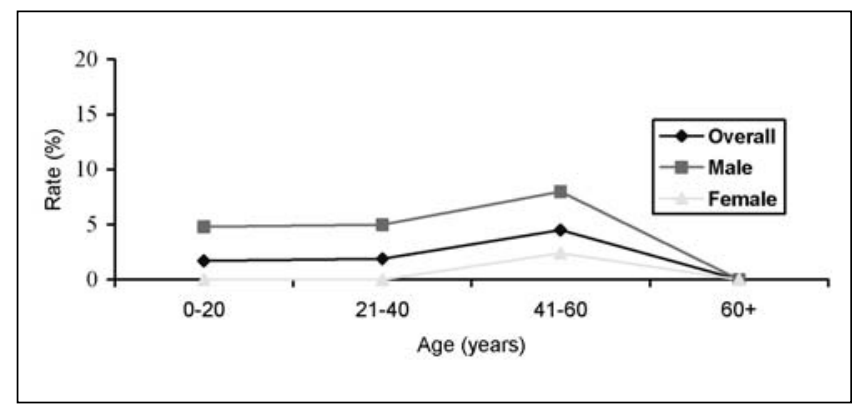

Figure 3) Anti-hepatitis $\mathrm{C}$ positive rates (\%) by age and sex in 315 inhabitants of a First Nations community in central Manitoba

versus $93.9 \%$, respectively). Age-specific prevalence rates for anti-HAV are provided for males, females and the entire study population in Figure 1. The majority (greater than $90 \%$ ) of the community were positive for anti-HAV before the third decade of life. The figure approached $100 \%$ by the age of 60 years.

\section{Hepatitis B}

A total of 301 sera (95.6\% of the study population) were available for anti-HBc testing. Of these, seven (2.3\%) tested positive. All seven were First Nations. Six of the seven were male. This figure represented $5.3 \%$ of all males tested. The one female represented $0.5 \%$ of all females tested. None of the anti-HBc positive sera was positive for $\mathrm{HBs} \mathrm{Ag}$.

Figure 2 provides the age-specific prevalence rates for anti$\mathrm{HBc}$ in males, females and the entire study population. One of the anti-HBc positive individuals was under the age of 20 years, three were between the ages of 21 and 40 years, three were between the ages of 41 and 60 and none was over the age of 60 years.

\section{Hepatitis C}

All 315 sera were available for anti-HCV testing. Seven (2.2\%) tested positive. All seven were First Nations. Three of the seven were male. The three males represented $2.5 \%$ of males tested and the four females, $2.0 \%$ of females. All seven samples were negative for HCV-RNA by RT-PCR.

Age-specific prevalence rates for anti-HCV in males, females and the entire study population are provided in Figure 3. One of the seven anti-HCV positive individuals was under the age of 20 years, five were between the ages of 21 and 40 years, one was between 41 and 60 years and none was beyond the age of 60 years.

To further explore the unusual finding of negative HCV RNA by RT-PCR in individuals positive for anti-HCV, we reviewed the Cadham Provincial Laboratory database for untreated HCV cases between January 1995 and June 2002. Of the total of 4633 anti-HCV positive entries, 4177 (90\%) were dervived from non-First Nations and 456 (10\%) First Nations subjects. Compared with the non-First Nations subjects, fewer First Nations subjects were HCV-RNA positive (90\% versus $86 \%$ respectively, $\mathrm{P}<0.004$ ), suggesting that $\mathrm{HCV}$ viremia is indeed less common in $\mathrm{HCV}$-infected First Nations peoples.

\section{DISCUSSION}

HAV is a single-stranded RNA virus that is spread via fecal contamination of food and drinking water (7). Thus, HAV outbreaks tend to occur in communities where personal hygiene measures, food preparation and water sterilization 
are suboptimal (8). Overcrowding and poor socioeconomic conditions are consistent findings where HAV prevalence rates are highest (9). The high prevalence of anti-HAV in this community ( $92 \%$ by the age of 20 ) is in keeping with a recent epidemic in the area. Such epidemics are known to occur every 10 to 15 years in rural and remote regions of the country (10). The data are also in keeping with results derived from Canadian Inuit settlements and developing nations throughout the world $(11,12)$. Together, these findings argue in favour of universal HAV vaccination for Canadian First Nations communities.

HBV is a double-stranded DNA virus that, in developing nations, is largely spread from mother to child at the time of birth (13). In developed nations, intimate exposure with an infected individual and injection drug use represent more common routes of transmission (14). The natural history of HBV infection depends to some extent on the route of viral acquisition. In maternal-infant transmission, infected individuals tend to become chronic carriers and remain $\mathrm{HBs}$ Ag positive for decades (15). On the other hand, transmission in adults results in a chronic carrier state in only $5 \%$ of infected individuals (13). In the present study, none of the seven exposed individuals (anti-HBc positive) was HBsAg positive, suggesting that transmission most likely occurred during adulthood. The relatively low overall infection rate $(2.3 \%$ anti-HBc positive versus $5 \%$ in the general Canadian population) may reflect the success of prenatal screening programs that exist in this population and/or better access and more prompt use of HBV immunoprophylaxis $(13,16,17)$.

HCV is a single-stranded RNA virus that is largely spread parenterally by injection drug use and, before 1990, by blood or blood product transfusion (18). A small percentage of infections (estimated to be less than 10\%) may be transmitted by nonparenteral routes such as intimate exposure with an infected individual or maternal-infant transmission (19). Whether HCV can be transmitted by insects and tick bites, common problems in this community, remains an issue of some debate (20). The relatively low prevalence of anti-HCV in this study population $(2.2 \%)$, compared with the estimated $0.8 \%$ for the general population and $21 \%$ in other high risk Manitoba populations, was a somewhat unexpected finding and suggests that despite the concerns of local health care givers and community elders, injection drug use may not be common amongst the inhabitants of this community $(21,22)$. That only one of the seven infected individuals was under the age of 20 years argues against both maternal-infant transmission and initiation of sexual activities as routes of transmission in these individuals; however, it must be noted that anti-HCV testing can remain positive for decades following viral clearance and individuals under the age of 15 years were discouraged from participating in the study (18). Unfortunately, the design of the study precluded attempts to ascertain whether and/or when infected individuals had received blood transfusions before 1990 or engaged in highrisk activities (injection drug use) in the past.

Previous studies have documented that approximately $75 \%$ of anti-HCV positive individuals will test positive for $\mathrm{HCV}$ RNA by RT-PCR (23). In the present study, none of the seven samples that was anti-HCV positive on repeat testing was HCV-RNA positive. Possible explanations for this finding include a false positive anti-HCV; methodological problems (sample and/or assay preparation) for HCV-RNA testing; infections occurring in the neonatal or early infant years; infection with a new HCV genotype; and enhanced spontaneous clearance rates. Regarding false positive anti-HCV testing, although the strengths of the anti-HCV were relatively low, varying between 0.84 and 15.33 SI (grey zone; 0.8 to 0.99, reactive greater than $1.0 \mathrm{SI}$ ), samples were only considered positive if they were positive on repeat testing. Unfortunately, sufficient sera and recombinant immunoblot assay testing were not available for this study. Thus, we cannot rule out the possibility these findings represent false positive results. With respect to sample preparation and assay performance, all sera were separated and frozen to the appropriate temperature within the time frame outlined for optimal HCV-RNA testing (24). The assay employed has a sensitivity of 100 viral copies $/ \mathrm{mL}(50 \mathrm{IU} / \mathrm{mL})$ and specificity of $98 \%$. Because most HCV carriers have viral loads in excess of $10^{5}$ copies/mL, the sensitivity of the assay should have been sufficient to identify viremia if present (25). Moreover, the finding that provincially, fewer anti-HCV positive First Nations subjects were HCV-RNA positive, compared with anti-HCV positive non-First Nations subjects, argues against a methodological problem, although the latter finding must be interpreted with caution given the large sample size. Of note, the reason why $86 \%$ of anti-HCV positive First Nations subjects in the provincial database were HCV-RNA positive versus $0 \%$ in the community population, is likely that the former group consists of individuals with clinical or biochemical evidence of liver disease and thus, are highly selected. Regarding neonatal and early infant exposure, these age groups are more often associated with spontaneous viral clearance (anti-HCV positive, HCV-RNA negative); however, the age specific prevalence rates for anti-HCV were not in keeping with this explanation (26). The absence of HCV-RNA precluded attempts to genotype the virus, and the fact that the primers employed target the conserved region of the viral genome renders a previously unidentified genotype an unlikely explanation for this finding. Finally, one must also consider whether the data reflect an inherent ability of First Nations peoples to spontaneously clear HCV. In support of this explanation are the provincial data described above and additional data indicating that Aboriginal people generate different cytokine profiles in response to certain mitogens and tend to have less severe chronic liver disease than non-Aboriginals when infected with other hepatotropic viruses (27-29). Clearly, further research in this area is warranted.

In summary, the results of this study indicate that HAV infection is common in this Canadian First Nations community but HBV and HCV prevalence rates are similar to those described in non-Aboriginals. These findings argue in favour of universal HAV vaccination and may reflect the benefits of prenatal HBV screening and immunoprophylaxis programs. Finally, the absence of HCV-RNA positivity in anti-HCV positive First Nations subjects remains unexplained. Further studies are required to confirm this finding and identify the mechanisms involved.

ACKNOWLEDGEMENTS: The authors thank Mrs S Zdanuk for her prompt and accurate typing of the manuscript and Health Canada for their financial support of this study. 


\section{REFERENCES}

1. Dusheiko GM. Treatment and prevention of chronic viral hepatitis. Pharmacol Ther 1995;65:47-73.

2. Martin JD, Mathias RG, Sarin C, Byrne SE. HIV and hepatitis B surveillance in First Nations alcohol and drug treatment centres in British Columbia, Canada, 1999-2000. Int J Circumpolar Health 2000;61:104-9

3. Albrecht CE. Circumpolar Health: Present and Future. Seattle and London: University of Washington Press, Circumpolar Health 1984;84:36-9.

4. Walsh K, Alexander GJ. Update on chronic viral hepatitis. Postgrad Med J 2001;77:498-505.

5. Larke RPB, Froese GJ, Devine RDO, Petruk MW. Extension of the epidemiology of hepatitis $\mathrm{B}$ in circumpolar regions through a comprehensive serologic study in the Northwest Territories of Canada. J Med Virol 1987;22:269-76.

6. Bernstein CN, McKeown I, Embil JM, et al. Seroprevalence of Helicobacter pylori, incidence of gastric cancer and peptic ulcerassociated hospitalizations in a Canadian Indian population. Dig Dis Sci 1999;44:668-74.

7. Mathiesen LR. The hepatitis A virus infection. Liver 1981;1:81-109.

8. Papaevangelou GJ, Gourgouli-Potiou KP, Vissoulis HG. Epidemiologic characteristics of hepatitis A virus infections in Greece. Am J Epidemiol 1980;112:482-6.

9. Szmuness W, Dienstage JL, Purcell RH, Harley EJ, Stevens CE, Wong DC. Distribution of antibody to hepatitis A antigen in urban adult populations. N Engl J Med 1976;295:755-9.

10. Varughese P. Canadian Diseases Weekly Report 1984;10-1:1-4.

11. Minuk GY, Waggoner JG, Jernigan R, Nicolle LE, Postl B, Hoofnagle JH. Prevalence of antibody to hepatitis A virus in a Canadian Inuit community. CMAJ 1982;127:850-2.

12. Burke DS, Snitbhan R, Johnson DE, Scott R. Age-specific prevalence of hepatitis A virus antibody to Thailand. Am J Epidemiol 1981;113:245-9.

13. Lee WM. Hepatitis B virus infection. Medical Progress N Eng J Med 1997;337:1733-45.

14. Goldstein ST, Alter MJ, Williams IT, et al. Incidence and risk factors for acute hepatitis B in the United States, 1982-1998: Implications for vaccinations programs. J Infect Dis 2002;185:713-9.

15. Lok ASF, Lai C-L. A longitudinal follow up of asymptomatic hepatitis B surface antigen-positive Chinese children. Hepatology 1988;8:1130-3.
16. Minuk GY, Uhnova J. Chronic hepatitis B infection in Canada. Can J Infect Dis 2001;12:351-6.

17. Okun NB, Larke RP, Waters JR, Joffres MR. Success of a program of routine prenatal screening for hepatitis $\mathrm{B}$ surface antigen: The first 2 years. CMAJ 1990;143:1317-21.

18. Lauer GM, Walker BD. Hepatitis C virus infection. N Engl J Med 2001;345:41-52.

19. Roudot-Thoraval F, Bastie A, Pawlotsky JM, Dhumeaux D. Epidemiological factors affecting the severity of hepatitis $\mathrm{C}$ virusrelated liver disease: A French survey of 6,664 patients. Hepatology 1997;26:485-90.

20. Wurzel LG, Cable RG. Can ticks be vectors for hepatitis $\mathrm{C}$ virus? N Engl J Med 2002,347:1724-5.

21. Zou S, Tepper M, Giulivi A. Hepatitis C in Canada. Can Commun Dis Rep 2001;27:13-5.

22. Moses S, Mestery K, Kaita K, Minuk GY. Viral hepatitis in a Canadian street-involved population. Can J Public Health 2002;93:123-8.

23. Alter MJ, Kruszon-Moran D, Nainan OV, et al. The prevalence of hepatitis $\mathrm{C}$ virus infection in the United States, 1988 through 1994. N Engl J Med 1999;341:556-62.

24. Davis GL, Lau J, Urdea MS, et al. Quantitative detection of hepatitis $C$ virus RNA with a solid-phase signal amplification method: Definition of optimal conditions for specimen collection and clinical application in interferon-treated patients. Hepatology 1994;19:1337-41.

25. Pawlotsky JM, Bouvier-Alias M, Hezode C, Darthuy F, Remire J, Dhumeaux D. Standardization of hepatitis C virus RNA quantification. Hepatology 2000;32:654-9.

26. Roberts EA, Yeung L. Maternal-infant transmission of hepatitis C virus infection. Hepatology 2002;36:S106-13.

27. Nickerson P, Dembinski I, Larcome L, Jamal A, Rigatto C, Orr P. Cytokine genotypes of North American Aboriginals with end-stage renal disease. Hum Immunol 2001;62:S62.

28. Minuk GY, Nicolle LE, Postl B, Waggoner JG, Hoofnagle JH. Hepatitis virus infection in an isolated Canadian Inuit (Eskimo) population. J Med Virol 1982;10:255-64.

29. Minuk GY, Orr PS, Brown R, Macdonald S, Chaudhary RK, Temple P. Pre-core mutant infections in the Canadian Inuit. J Hepatol 2000;33:781-4. 


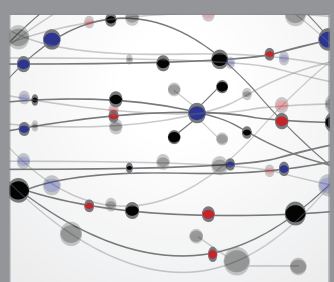

The Scientific World Journal
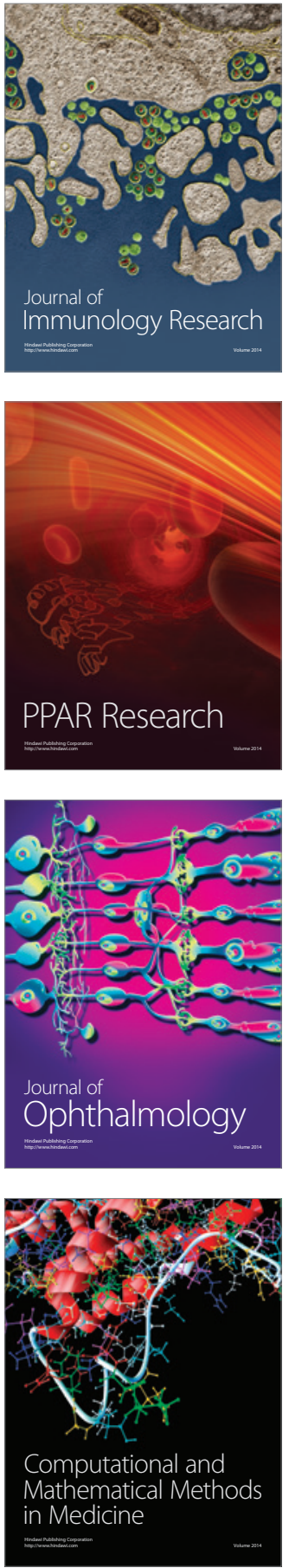

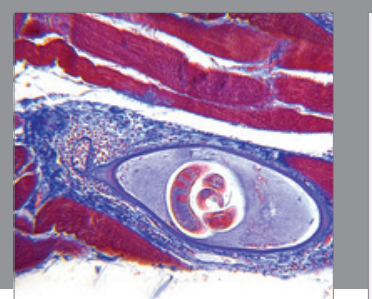

Gastroenterology Research and Practice

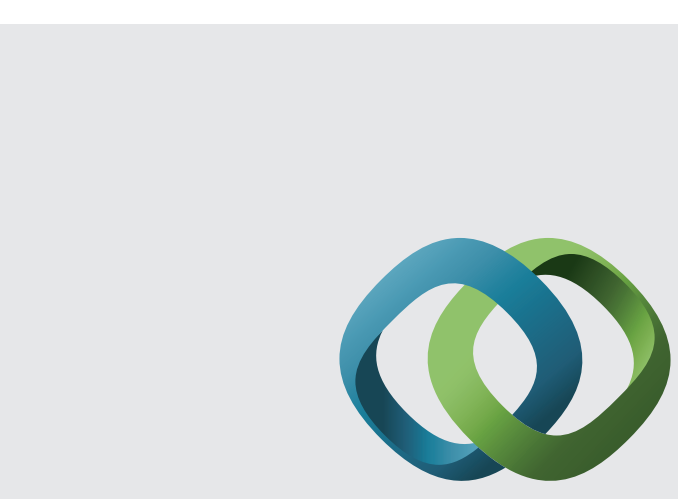

\section{Hindawi}

Submit your manuscripts at

http://www.hindawi.com
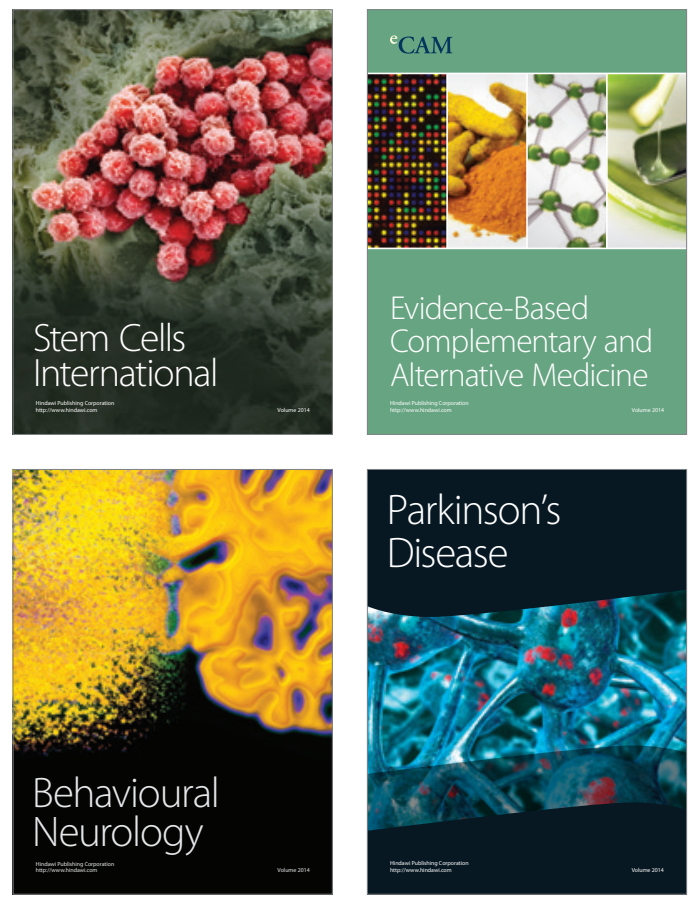
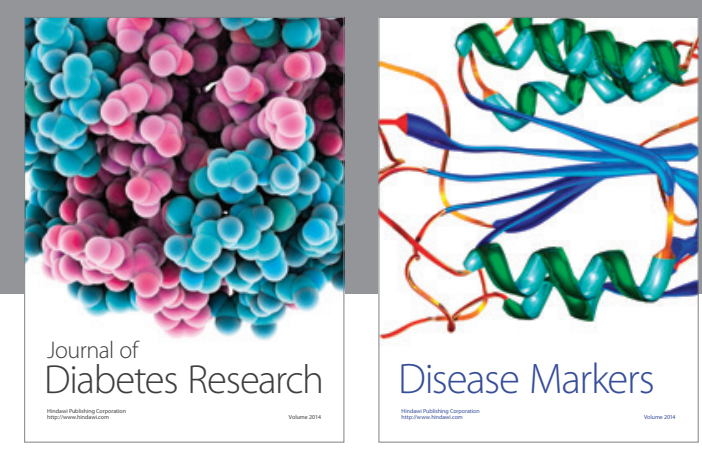

Disease Markers
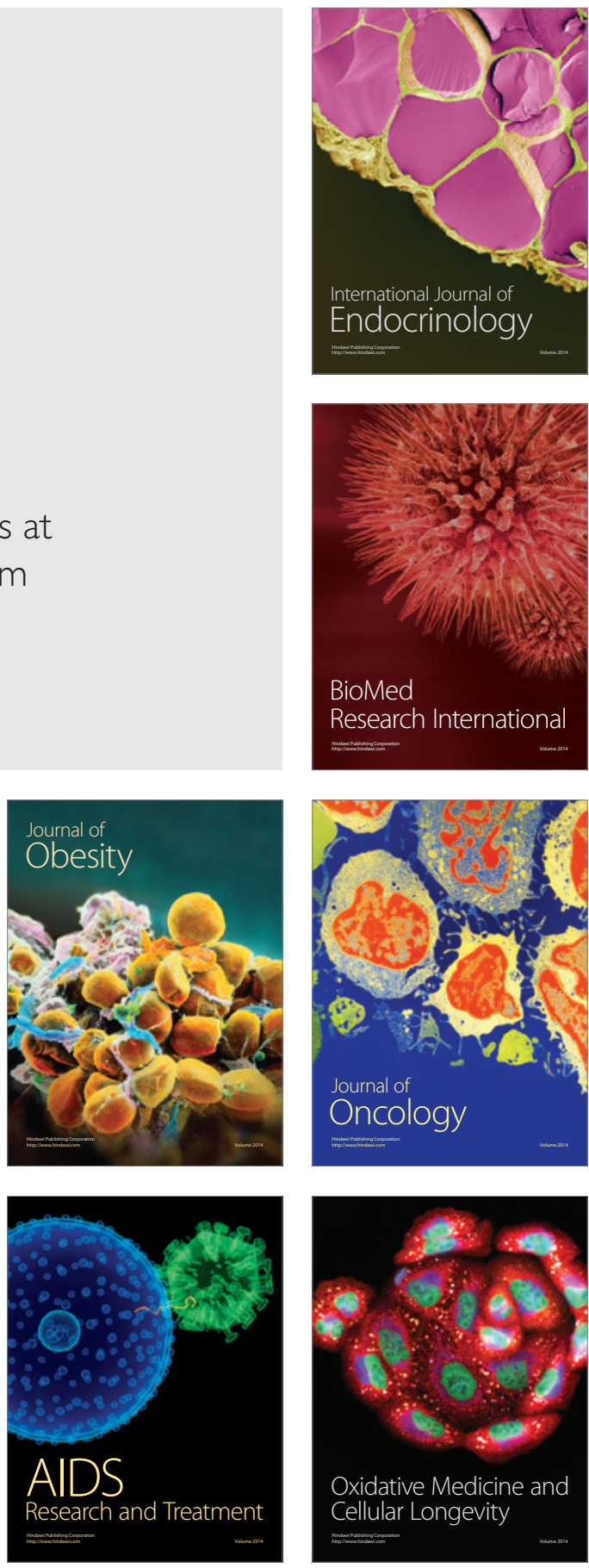